\title{
Environmental evaluation of waste treatment scenarios for the towns Khanty-Mansiysk and Surgut, Russia
}

Waste Management \& Research 31(3) 315-326

(c) The Author(s) 2013

Reprints and permission:

sagepub.co.uk/journalsPermissions.nav DOI: 10.1177/0734242X12473792

wmr.sagepub.com

(S)AGE

\author{
Julia Kaazke ${ }^{1}$, Montse Meneses ${ }^{2}$, Berndt-Michael Wilke ${ }^{1}$ and Vera \\ Susanne Rotter ${ }^{3}$
}

\begin{abstract}
Khanty-Mansiysk Autonomous Okrug - Ugra in Siberia has recently started to play a major role in the Russian economy because key oil and gas extraction sites are located in this region. As a result, the extensions of infrastructure and higher incomes have been leading to an accelerated population growth and consequent increase in the generation of solid household waste. The current methods of waste disposal have now reached their limits, especially in the towns Khanty-Mansiysk and Surgut. The key objectives of this study were to identify the influence of waste composition and transport routes on the life cycle assessment (LCA) results and to assess the current waste treatment option for solid household waste and to compare it with proposed scenarios. Furthermore, recommendations for an optimal use of LCA within a decision-making process for a waste management plan are presented. LCA methodology was used to evaluate different waste management scenarios such as landfilling and incineration. One result was that the options 'incineration with recycling' and 'anaerobic mechanical-biological treatment with recycling' demonstrated lower environmental impact in both Khanty-Mansiysk and Surgut. Another finding was that there were hardly any differences in the ranking of the scenarios for Surgut and Khanty-Mansiysk. However, the special socio-cultural circumstances and location of each town have to be considered seriously in the development of a sustainable waste management plan.
\end{abstract}

\section{Keywords}

Life cycle assessment (LCA), environmental evaluation, landfill, incineration, mechanical-biological treatment (MBT), waste management, mechanical-biological treatment plant, Russia

\section{Introduction}

The region of Khanty-Mansiysk Autonomous Okrug - Ugra (KMAO-Ugra) is located in Western Siberia in the Russian Federation (Figure 1). The size of the area is $534800 \mathrm{~km}^{2}$. Only $1.3 \%$ of the area is covered by towns and villages as well as roads and industrial areas (Government of KMAO-Ugra, 2004).

The climate is almost continental in KMAO-Ugra, with an average temperature range between -18 and $-24^{\circ} \mathrm{C}$ in January, and 16 to $18{ }^{\circ} \mathrm{C}$ in July (Administration of KMAO-Ugra, 2011a). Temperatures below zero degrees Celsius and snowfall are recorded for seven months per year, from October to April (Administration of KMAO-Ugra, 2011b). Average rainfall rate is 400-550 mm year ${ }^{-1}$ in KMAO-Ugra (Administration of KMAOUgra, 2011c).

Since the mid-1990s, the population has been growing as a result of the development of the oil and gas industry in KMAOUgra. In January 2011, KMAO-Ugra's population was approximately 1.52 million, and it has a very sparse population density with an average of 2.8 persons $\mathrm{km}^{-2}$. A total of $91.5 \%$ of the entire population of KMAO-Ugra live in the 15 regional cities (Administration of KMAO-Ugra, 2011a). There has been a migration boom particularly in the capital of KMAO-Ugra, Khanty-Mansiysk. Whereas in 1995, a total of 35300 inhabitants were registered in Khanty-Mansiysk, the population has increased rapidly from 39000 in 2000 to 78000 in 2010 (Kornienko, 2011). The area of the town is $33.7 \mathrm{~km}^{2}$. Khanty-Mansiysk is only an administrative town, and there are no industries present (F. Tomsha, Head of Communal Service in Khanty- Mansiysk, personal communication 29 January 2007). In contrast to Khanty-Mansiysk, Surgut covers an area of $213 \mathrm{~km}^{2}$ with a population of

IInstitute of Ecology, Technische Universität Berlin, Berlin, Germany

2Department of Telecommunications and Systems Engineering,

Escola d'Enginyeria, Universitat Autònoma de Barcelona, Bellaterra, Spain

3nstitute of Environmental Technology, Technische Universität Berlin, Berlin, Germany

\section{Corresponding author:}

Julia Kaazke, Institute of Ecology, Technische Universität Berlin BH-1, Ernst-Reuter-Platz 1, 10587 Berlin, Germany.

Email: jkaazkedgmx.de 


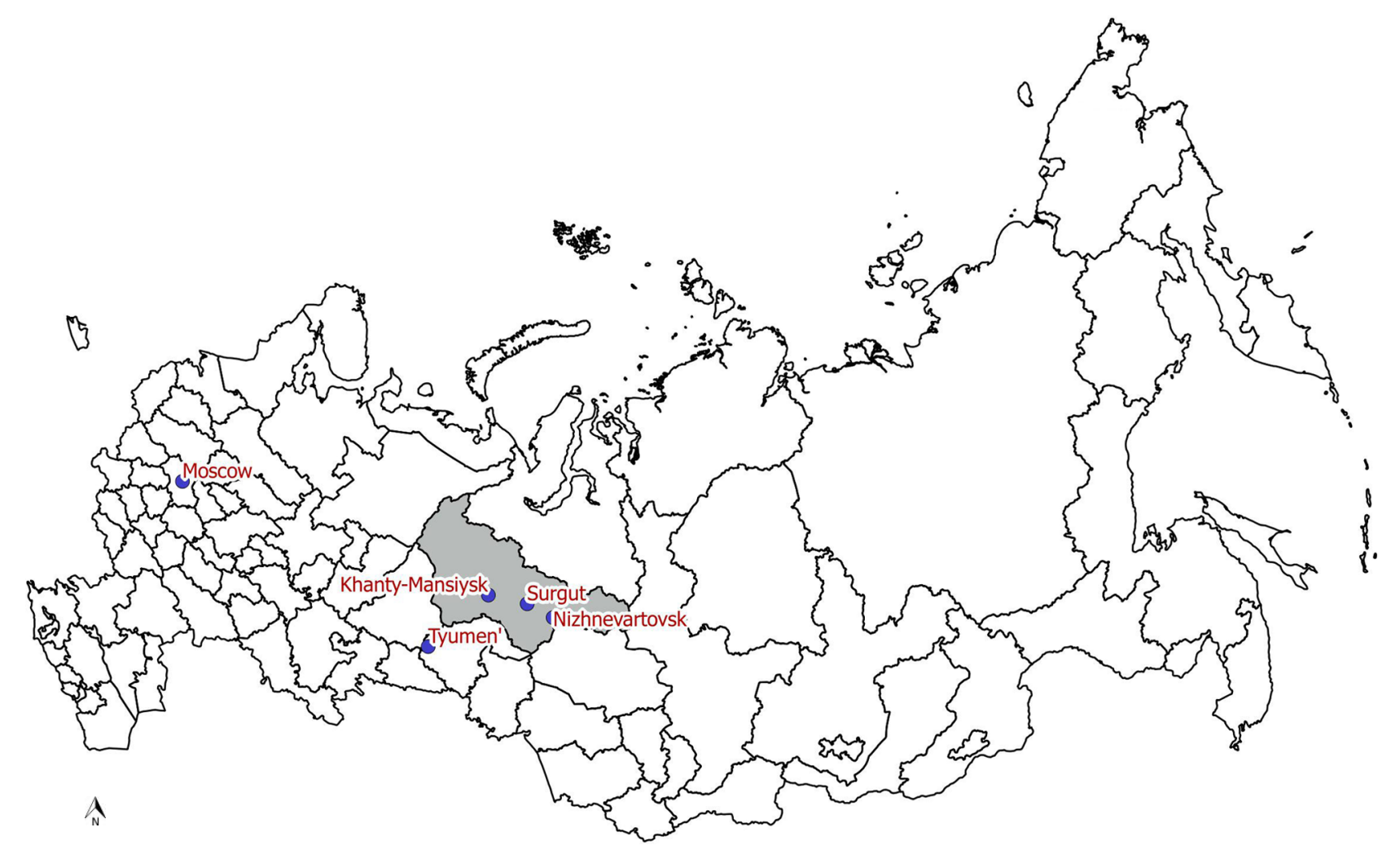

Figure 1. Geographical position of Khanty-Mansiysk Autonomous Okrug (without scale). (Source: Fillipova, 2011).

approximately 298 000. It is also the cultural and industrial centre in the region (Administration of KMAO-Ugra, 2011a).

As a result of the migration boom, higher incomes and an improved infrastructure, the generation of municipal waste has accelerated in both Khanty-Mansiysk and Surgut. Therefore, a continuous increase in the amount of waste for disposal has been recorded in Khanty-Mansiysk and Surgut for several years, and the current methods of waste disposal have reached their limits. As a consequence, the management of solid household waste is currently one of the biggest problems in both cities.

The disposal of all mixed solid household waste on a landfill is the current waste management solution. One governmental landfill has existed in Khanty-Mansiysk since 1999 with a planned capacity of $518970 \mathrm{~m}^{3}$ (F. Tomsha, personal communication, 29 January 2007), and in Surgut since 1994 with a planned capacity of $8650000 \mathrm{~m}^{3}$ (E. Kiseleva, Department of Environmental Control, Rosthekhnadzor, personal communication, 10 August 2008). These landfills, which are either partly or entirely unsealed, are used for deposition of all types of waste. These issues result in the improper disposal of waste and cause environmental problems and risks to human health and demonstrate the necessity of developing a sustainable waste management plan in both towns.

However, the development of a waste management plan for the town Khanty-Mansiysk depends on the requirements that are given by Russian waste legislation. The Constitution of the Russian Federation (2008) and the key act regarding waste management (Federal Law on Industrial and Municipal Waste, 2008) describe the objectives. The major aims of these laws are to prevent a negative impact on human health and the environment caused by improper waste disposal and to implement the recycling of materials from waste as a source for commodities and economic revenues. As sustainable waste management plans should achieve these aims, an assessment during the development of the plan with regard to future environmental impact is necessary.

\section{Decision support tools for the environmental assessment of waste management options}

Several methodologies such as environmental risk assessment (ERA), environmental impact assessment (EIA) and life cycle assessment (LCA) have been developed in order to evaluate the ecological consequences of waste treatment. Only the latter includes the evaluation of an integrated system, whereas ERA and EIA place their main emphasis on a single process or facility such as incineration. LCA follows the holistic approach, i.e. it was developed in order to evaluate the environmental impact of products or processes throughout their entire life: from the beginning as raw material through production and use to disposal (Hauschild and Barlaz, 2007; OECD 2008; Tukker, 2000); for EIA compare also EC (2001) and for ERA compare also Lipworth (2008).

LCA is mostly implemented via software programmes as due to its holistic approach, it requires a large volume of data for the assessment of possible environmental impact. In addition, the software programme can assist in developing scenarios, to subdivide the entire process into different parts, and hence, to present 
the results of the individual parts or the whole procedure (Unger et al., 2008).

As a part of the project 'The Use of Life Cycle Assessment Tool for the Development of Integrated Waste Management Strategies for Cities and Regions with Rapidly Growing Economies (LCA-IWM)' the LCA-IWM assessment tool was developed (Den Boer et al., 2007; TU Darmstadt, 2005). The aim of LCA-IWM is to support decision-makers regarding the development of waste management plans in regions with fast economic growth; i.e. a rapid increase of gross domestic product. Default data are, among others, the key type of energy production in the country or average emissions which contribute to global warming, or size and material of waste containers, type and size of waste disposal trucks, etc. and are available in this programme for different countries, such as Lithuania. In this respect, it differs from the other LCA models which usually offer a data set for only one country. As Lithuania shares a common history within the Soviet Union, it was assumed that the default data of Lithuania can be used for the simulation of waste management options in Russia and specifically for Khanty-Mansiysk and Surgut.

\section{Objectives}

The objective of this article is to present an assessment of the environmental impact of the current waste management system in Khanty-Mansiysk and Surgut compared to alternative waste management. The influence of waste composition and transport routes on the LCA-IWM assessment results was determined in sensitivity analyses. An optimal solution of waste treatment for both Khanty-Mansiysk and Surgut in consideration of the specifics of the spatial conditions in Siberia is discussed and recommendations for optimal usage of an LCA within a decision-making process are developed.

\section{Material and methods}

\section{Description of LCA-IWM}

As described in ISO 14040:2006-Environmental Management-LCA-Principles and Framework (ISO, 2006), an LCA is subdivided into four parts which are explained for the software LCA-IWM assessment tool in the following subsections.

Definition of goal and scope. The goal is to assess from an environmental point of view the current solid household waste treatment scenario with some proposed scenarios for KhantyMansiysk and Surgut and to discuss an optimal solution for waste treatment. The assessment boundaries begin with the waste disposal in the waste containers, continue with the collection and transport and end with treatment and disposal (Den Boer et al., 2007; TU Darmstadt, 2005).

Life cycle inventory. Common data sets for emissions of pollutants and consumption of resources are used for the environmental assessment in the project. The origins of these data sets are countries with an advanced developed waste management system (den Boer et al., 2007; TU Darmstadt, 2005).

Life cycle impact assessment. The functional unit within the application of the LCA-IWM assessment tool is the total amount of waste generated in the research area which enters the waste management cycle in one year. 'CML 2001' is the impact assessment tool used within the LCA-IWM. In order to enable the comparison of the results of each category, the results were normalized as 'inhabitant equivalent', which describes the normalization factor. The 'world inhabitant equivalent' was used as the normalization factor in this study. The impact categories which are provided in this LCA-IWM tool are: abiotic depletion, global warming, human toxicity, photochemical oxidation, acidification and eutrophication (Den Boer et al., 2007; TU Darmstadt, 2005).

Interpretation. The results are evaluated and an optimal approach to an environmental domestic waste treatment is discussed (Den Boer et al., 2007; TU Darmstadt, 2005).

\section{Development of waste treatment scenarios}

Seven scenarios for possible solid household waste treatments for Khanty-Mansiysk and Surgut were proposed. The aim of all these approaches to waste treatment is to achieve a reduction of environmental impact caused by waste disposal management. Furthermore, the current situation (scenario 1 'landfill') was also modelled for the LCA-IWM assessment tool in order to compare it with the alternative waste treatments (Table 1).

Aerobic mechanical-biological treatment plants (aeMBT), anaerobic mechanical-biological treatment plants (anMBT) and incineration plants were selected as they can treat mixed solid household waste. As each scenario includes a landfill for deposition of residual waste, the local conditions of landfill and transport routes in Khanty-Mansiysk and in Surgut were assumed for each scenario:

- This landfill is not equipped with a gas or leachate collection system.

- The waste is transported to treatment plants and/or to a landfill by waste disposal trucks.

Four scenarios (scenarios 1 to 4 ) do not consider recycling whereas four of the scenarios (scenarios 5 to 8 ) do include (source) separation and recovery of recyclables. A 20\% recycling rate was assumed. The main differences between scenarios with and without recycling are:

- all scenarios with recycling require different and more waste bins as well as waste collection trucks in contrast to the scenarios without recycling.

- all scenarios with recycling include a transfer station and therefore several transport routes: waste transport from waste collection point to the transfer station, and from there to the different treatment plants that the recyclable materials have to 
Table 1. Summary of scenarios for future waste management in Khanty-Mansiysk and Surgut.

\begin{tabular}{|c|c|c|c|c|c|c|c|}
\hline \multirow{2}{*}{$\begin{array}{l}\text { Name of the } \\
\text { scenario }\end{array}$} & \multicolumn{7}{|l|}{ Content of each scenario } \\
\hline & $\begin{array}{l}\text { Separate cllection } \\
\text { and rcycling of } 20 \% \\
\text { of electronics, glass, } \\
\text { paper, plastics, metals }\end{array}$ & $\begin{array}{l}\text { Treatment } \\
\text { of MSW in } \\
\text { aeMBT }\end{array}$ & $\begin{array}{l}\text { Treatment } \\
\text { of MSW in } \\
\text { anMBT }\end{array}$ & $\begin{array}{l}\text { Treatment } \\
\text { of MSW in } \\
\text { incineration } \\
\text { plant }\end{array}$ & $\begin{array}{l}\text { Recycling of metals } \\
\text { (separated in the } \\
\text { process of MBT) }\end{array}$ & $\begin{array}{l}\text { Use of } \\
\text { RDF }\end{array}$ & $\begin{array}{l}\text { Landfilling of } \\
\text { rejects }\end{array}$ \\
\hline Scenario 1 'landfill' & & & & & & & $\begin{array}{l}\text { landfilling of } \\
\text { untreated MSW }\end{array}$ \\
\hline Scenario 2 'aeMBT' & & $x$ & & & $x$ & $x$ & $x$ \\
\hline Scenario 3 'anMBT' & & & $x$ & & $x$ & $x$ & $x$ \\
\hline $\begin{array}{l}\text { Scenario } 4 \\
\text { 'incineration' }\end{array}$ & & & & $x$ & & & $x$ \\
\hline $\begin{array}{l}\text { Scenario } 5 \text { 'landfill } \\
\text { and recycling' }\end{array}$ & $x$ & & & & & & $\begin{array}{l}\text { plus untreated } \\
\text { MSW }\end{array}$ \\
\hline $\begin{array}{l}\text { Scenario } 6 \text { 'aeMBT } \\
\text { and recycling' }\end{array}$ & $x$ & $x$ & & & $x$ & $x$ & $x$ \\
\hline $\begin{array}{l}\text { Scenario } 7 \text { 'anMBT } \\
\text { and recycling' }\end{array}$ & $x$ & & $x$ & & $x$ & $x$ & $x$ \\
\hline $\begin{array}{l}\text { Scenario } 8 \\
\text { 'incineration and } \\
\text { recycling' }\end{array}$ & $x$ & & & $x$ & $x$ & & $\times$ \\
\hline
\end{tabular}

be transferred to. In contrast, the transport route in scenarios 1 to 4 consists of only one way - from the waste collection point to the treatment plant/landfill.

\section{Data basis for use of the LCA-IWM assessment tool}

The tool requires site-specific data on waste amount and composition to be entered. For this study these data were determined within an extended waste analysis covering the time from May 2006 to August 2008, including eight campaigns where a total of $6 \mathrm{Mg}$ of waste were sorted (for detailed information about implementation of waste analyses in Khanty-Mansiysk and Surgut compare Kaazke (2010)).

In order to compare the results from both cities the waste amount per capita was calculated by accounting for 10000 inhabitants in each town; namely in Khanty-Mansiysk and in Surgut.

The annual per capita amount of solid household waste is given in Table 2 .

\section{Sensitivity analysis of waste composition}

LCA-IWM requires a lot of input data which, especially when derived from literature and/or are estimated, may contain uncertainties. Therefore, testing the robustness of results of LCA via sensitivity analysis is recommended (compare also Cariboni et al., 2007; Eriksson et al., 2002; Helton et al., 2006). In KhantyMansiysk, the four seasonal analyses were subdivided into analyses of the residential structure 'apartment blocks' and analyses of the residential structure 'small houses with gardens'. The results of the seasonal compositions of the residential structure 'small houses with gardens' for Khanty-Mansiysk were used to carry out the sensitivity analysis as these results showed noticeable deviations among the seasons (Table 3).

\section{Sensitivity analysis of spatial conditions}

If the waste has to be transported to a central treatment plant, for example from Khanty-Mansiysk to Surgut, the distances of waste transport could also have an influence on environmental impact. More waste collection trucks are necessary, which would result in a higher consumption of petrol and diesel and higher emissions. Therefore, the distance from Khanty-Mansiysk to Surgut (250 km) was taken for scenarios 5-8 for the transport of waste. A shorter distance $(17 \mathrm{~km})$ was chosen for scenarios $1-4$ for the transport of the waste from the town to the waste treatment plant/ landfill. The aim was to compare the results of the LCA-IMW assessment tool with regard to long and short distances.

\section{Results}

\section{Waste amount balance}

One of the key aims of sustainable waste management plans is the reduction of waste disposed off on the landfill as well as the production of refuse-derived fuel (RDF) and usage of secondary materials for energy recovery. Therefore, all waste amount balances for each scenario were identified (Table 4). The following results were obtained.

- Scenario 8 'incineration and recycling' for Khanty-Mansiysk and for Surgut reduced the waste amount for landfilling the most, especially as the material (mainly slag) can be used for road construction and so it is not disposed of to the landfill.

- Scenario 7 'anMBT and recycling' produced the highest volume of RDF.

- Scenario 3 'anMBT' yielded the greatest amount of metals for recycling, with $132 \mathrm{Mg}$ year $^{-1}$ in Khanty-Mansiysk and $77 \mathrm{Mg}$ year $^{-1}$ in Surgut. 
Table 2. Amount of solid household waste for the years 2007/2008 and forecasted for 2012 as well as annual average of the relative waste composition based on four sorting analyses in 2006-2008 in Khanty-Mansiysk and Surgut (source: Kaazke, 2010).

\begin{tabular}{|c|c|c|}
\hline Waste amount & $\begin{array}{l}\text { Khanty-Mansiysk } \\
\text { (kg capita-1 year-1) }\end{array}$ & $\begin{array}{l}\text { Surgut } \\
\left(\mathrm{kg} \mathrm{capita}^{-1} \text { year-1) }^{-1}\right.\end{array}$ \\
\hline $2007 / 2008$ & 347 & 224 \\
\hline 2012 & 372 & 246 \\
\hline $\begin{array}{l}\text { Functional unit for using the LCA-IWM } \\
\text { assessment tool/ } \\
\text { Waste amount used in the LCA-IWM }\end{array}$ & 3720000 & 2460000 \\
\hline Waste composition & $\begin{array}{l}\text { Khanty-Mansiysk } \\
(w / w \%, n=4)\end{array}$ & $\begin{array}{l}\text { Surgut } \\
(\mathrm{w} / \mathrm{w} \%, n=4)\end{array}$ \\
\hline Organics (kitchen) & 30.3 & 27.4 \\
\hline Organics (garden) & 5.9 & 4.5 \\
\hline Plastics & 13.0 & 16.7 \\
\hline Glass & 14.6 & 20.0 \\
\hline Paper/cardboard & 11.1 & 9.6 \\
\hline Metals & 4.6 & 4.0 \\
\hline Electronics & 0.2 & 0.2 \\
\hline Hazardous waste & 0.5 & 0.0 \\
\hline Residual & 19.7 & 17.6 \\
\hline Total & 100.0 & 100.0 \\
\hline
\end{tabular}

$n$ is the number of waste analyses implemented; i.e. $n=4$ times.

Table 3. Seasonal waste composition of residential structure 'small houses with gardens' of Khanty-Mansiysk (w/w \%).

\begin{tabular}{|c|c|c|c|c|}
\hline \multirow[t]{2}{*}{ Waste fractions } & \multicolumn{4}{|c|}{ Seasons } \\
\hline & Spring & Summer & Autumn & Winter \\
\hline Organics (kitchen) & 13.9 & 30.6 & 21.9 & 26.6 \\
\hline Organics (garden) & 15.8 & 2.7 & 31.4 & 0.8 \\
\hline Plastic & 9.1 & 14.1 & 8.6 & 17.4 \\
\hline Glass & 11.5 & 14.3 & 7.0 & 16.4 \\
\hline Paper/cardboard & 6.1 & 7.8 & 9.9 & 9.6 \\
\hline Metals & 10.9 & 9.7 & 7.7 & 4.6 \\
\hline Electronics & 2.3 & 0.0 & 0.2 & 1.2 \\
\hline Hazardous & 1.3 & 1.7 & 0.2 & 0.4 \\
\hline Residual & 29.2 & 19.2 & 13.0 & 22.9 \\
\hline Total & 100.0 & 100.0 & 100.0 & 100.0 \\
\hline
\end{tabular}

- Scenario 7 'anMBT and recycling' produces the highest volume of materials for recycling.

\section{Impact categories and ranking list}

The environmental impact assessment results of the modelling for all eight scenarios are presented in Table 5. A negative figure of the results of the LCA-IWM assessment tool signifies an environmental credit/benefit; a positive figure means an environmental burden.

In order to enable the comparison of results of each category, the results of Table 5 were normalized into 'world inhabitant equivalents'. The overall results of the LCA assessment tool are given in Figure 2 demonstrate that the impact categories abiotic depletion, global warming, and acidification have a key influence on the environmental assessment for each scenario proposed for
Khanty-Mansiysk and Surgut. The impact category abiotic depletion in particular largely indicates an environmental credit for all scenarios, with the exception of scenario 1 'landfill'. Human toxicity, photo-oxidation and eutrophication have only secondary influence on the overall results of the environmental assessment for each scenario. It can be observed that the indicator 'global warming' presents an environmental benefit for scenarios 3, 6, 7 and 8 for Khanty-Mansiysk and for scenarios 3, 6 and 7 for Surgut. This is due to the energy recovery in the case of incineration treatment (scenario 8) or aeMBT (scenario 6) and anMBT (scenarios 3 and 7). Another important point is that when recycling is included, the environmental impact of the scenarios is considerably reduced. Scenario 7 'anMBT with recycling' presents a considerable reduction in comparison with scenario 3 'anMBT'.

A comparison of the results of the environmental assessment demonstrates that scenario 1 'landfill' is the scenario with the highest environmental burden as all impact categories indicate burdens for the environment. All other scenarios demonstrate less environmental impact and show the same ranking list in respect of environmental impact in Khanty-Mansiysk and in Surgut (Figure 2).

\section{Sensitivity analysis of waste composition}

Seasonal waste compositions have an influence on the overall result of the impact categories, especially on global warming in the example scenario 8 'incineration with $20 \%$ recycling' in Khanty-Mansiysk (Figure 3). For instance, the composition of waste analysed in winter has a negative rather than a positive effect on the impact category 'global warming'. The main differences in waste composition during the different seasons are that 


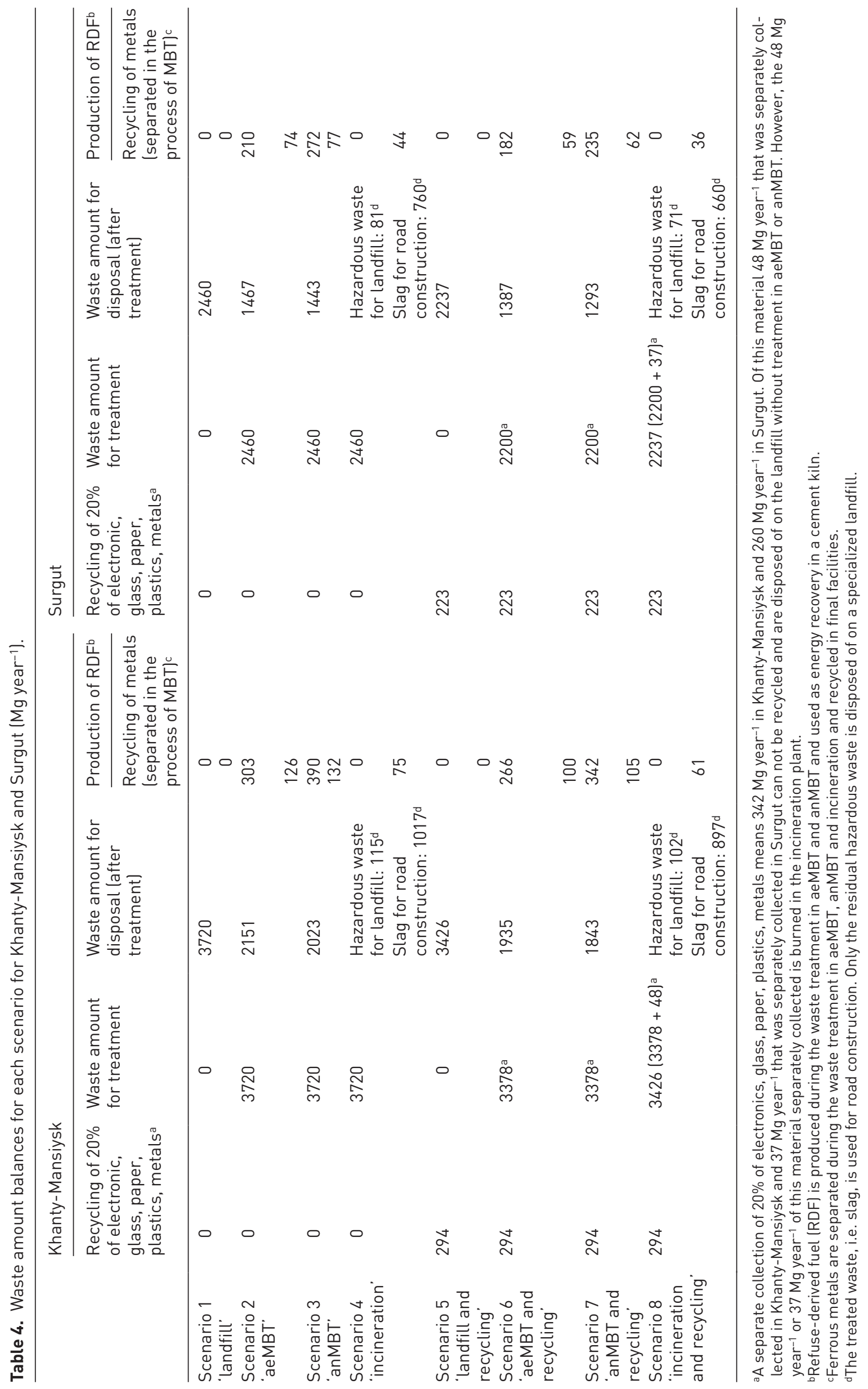




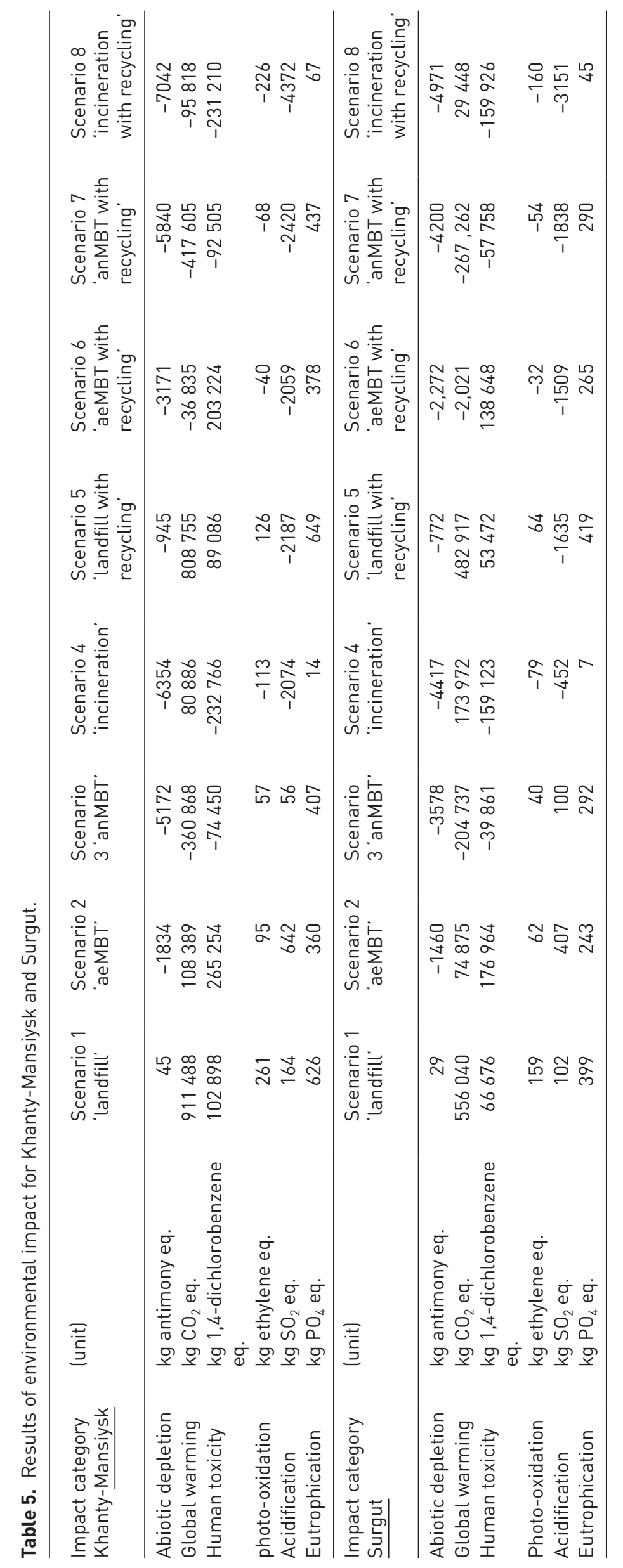




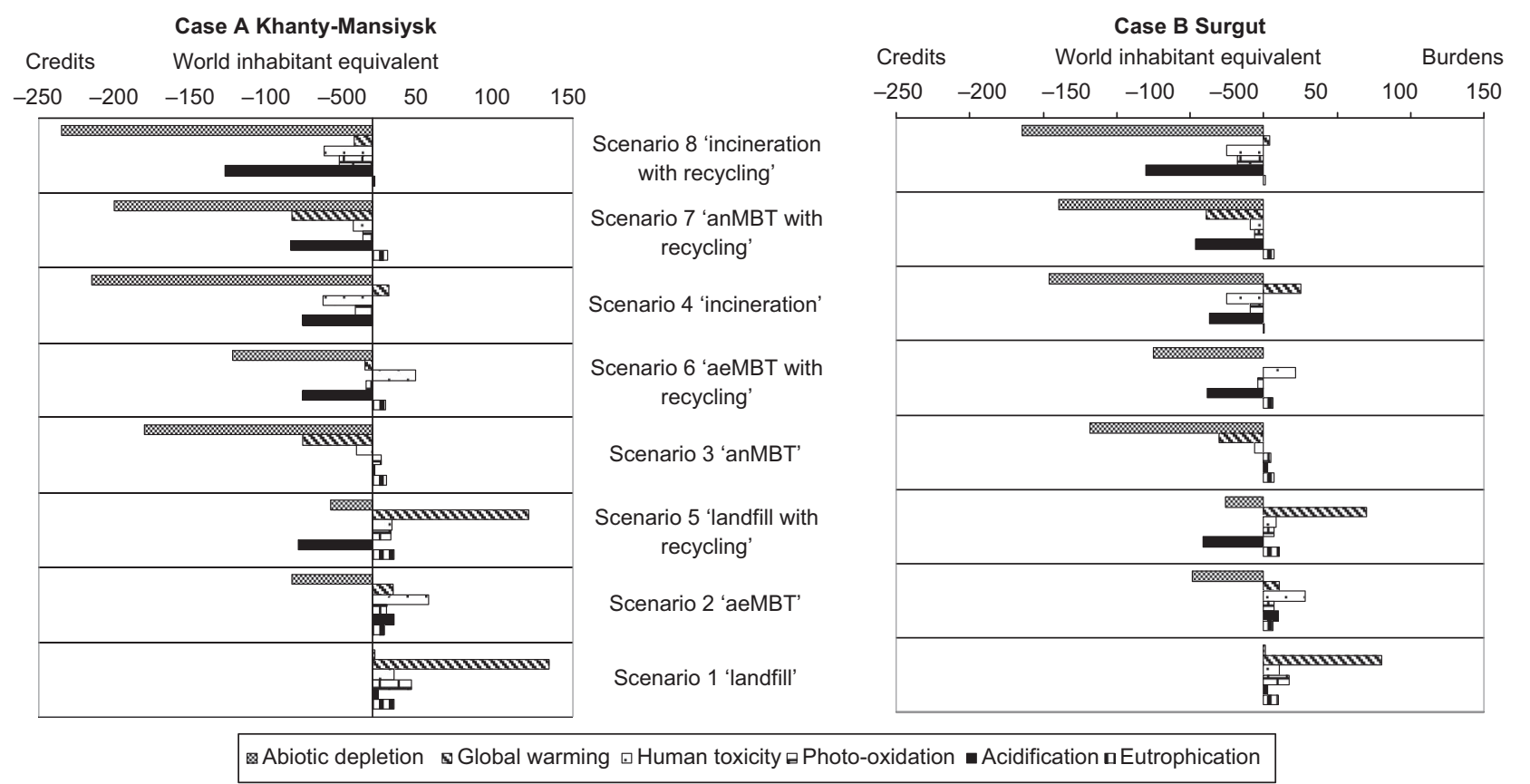

Figure 2. Environmental assessment of waste management system for Khanty-Mansiysk and in Surgut.

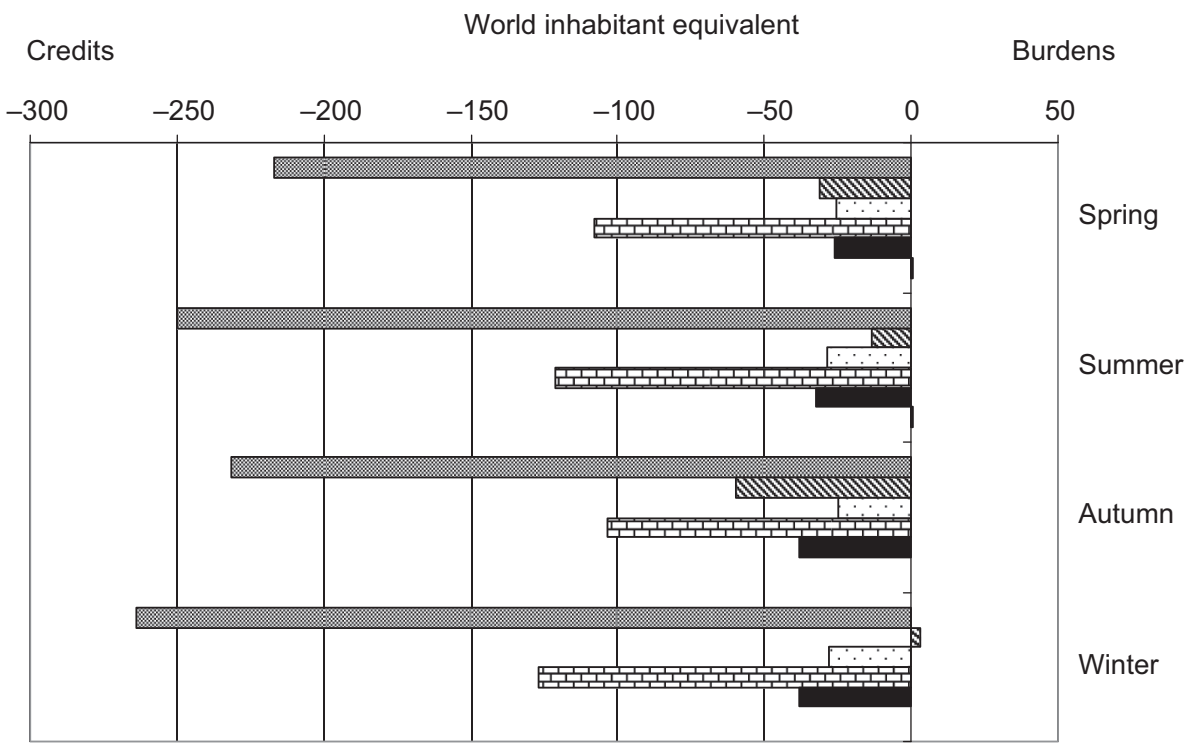

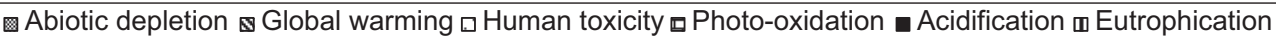

Figure 3. Results regarding sensitivity analyses of seasonal waste composition in Khanty-Mansiysk for scenario 8 'incineration with $20 \%$ recycling'.

the organic fraction is significantly higher in autumn. Besides the fraction plastics, organic is the key waste fraction for the impact category global warming.

\section{Sensitivity analysis of spatial conditions}

The overall results of each impact category can also be composed of the results for the environmental impact of 'treatment plants' (including landfill), 'collection and transport' and 'temporary storage' (disposal in waste containers). In Table 6, scenario 1 'landfill' and scenario 5 'landfill with recycling' for KhantyMansiysk serve as examples for the subdivision of the overall results of each impact category into single results of the impact of 'treatment plants', 'collection and transport' and 'temporary storage'.

The assessment demonstrated that the stage of the waste management system 'treatment plant' has the greatest influence on the overall result within each impact category. The example also shows that the influence of 'temporary storage' and 'collection and transport' on the overall result of each impact category is 
always negative; namely a burden on the environment. Scenario 5 'landfill with recycling' demonstrates a higher impact on the environment within 'collection and transport' for each category in contrast to scenario 1 'landfill' caused by longer transport routes for the recycled materials. An influence on each impact category is evident: The greater the distance, the greater the burden on the environment and vice versa: the shorter the distance, the lower the environmental burden.

\section{Discussion and recommendations}

Influence on assessment results of waste amount and waste composition. The results of the LCA-IWM assessment tool clearly show that recycling can reduce the environmental burden. In a comparison of scenario 1 'landfill' with scenario 5 'landfill with recycling' of Khanty-Mansiysk, for instance, the results demonstrate that the impact categories 'abiotic depletion' and 'acidification' are a burden instead of a credit. The higher the recycling yield, the greater the environmental credit (see Figure 2 ). Less waste amount per capita in Surgut (224 kg capita ${ }^{-1}$ year $\left.^{-1}\right)$ - in contrast to Khanty-Mansiysk (347 kg capita ${ }^{-1}$ year $^{-1}$ ) - results in less environmental impact. Consequently, all results of the LCA-IWM assessment tool show less environmental burden and credit per capita for Surgut than for Khanty-Mansiysk in every scenario.

The sensitivity analysis of waste composition clearly demonstrates that waste composition can increase or reduce environmental burdens within the assessment. Knowledge of waste composition and waste amount are essential for modelling scenarios while using an LCA tool. Waste composition and amount determine the waste management and can have a major effect on the results of LCA tools (compare Gentil et al., 2010). Zhao et al. (2009) showed similar results; fewer plastic bags in the waste reduces the negative environmental impact. Therefore, waste amount and composition play a key role in the development of a waste management plan and must be given serious consideration.

The results of the LCA-IWM assessment tool also demonstrate that the current situation of waste management, scenario 1 'landfill', is the worst environmental waste management scenario, a fact which is also accepted globally (UNEP, 2004). Thus, there is an urgent need to improve the waste management plans in Khanty-Mansiysk and Surgut.

Influence of assessment results of spatial conditions of Khanty-Mansiysk and Surgut. Hong et al. (2010) observed a negligible impact of transport for the overall environmental assessment within LCA research. Luoranen et al. (2009) indicated that the distances of waste transport routes play a role for the environmental assessment. The present study affirms these results and indicates an influence of distance on environmental evaluation: the greater the distance, the greater the burden for the environment.

Due to the remoteness of Khanty-Mansiysk and in contrast to Surgut, the environmental assessment of transport of waste/recycling materials plays an important role and the analysis of transport distances clearly demonstrates that it will always have a negative effect on each impact category. 
Consideration of economic and social criteria for the development of sustainable waste management planning. Although the results of the LCA assessment tool showed a similar ranking list, Khanty-Mansiysk and Surgut demonstrate different starting points for implementing sustainable waste management plans.

Khanty-Mansiysk is only an administrative town, and there are no industries present. It is growing rapidly in contrast to Surgut, and therefore the development of infrastructure and the town itself is presumed to have an influence on the current waste management system since the system is not designed to cope with the current amounts. In contrast to Khanty-Mansiysk, Surgut is characterized by a lot of industry; it delivers many products into KMAO-Ugra. There is no migration boom similar to that observed in Khanty-Mansiysk at present. Therefore, not only does environmental impact play an important role in the implementation of a sustainable waste management plan, economic conditions and social acceptance also play a part (compare Bovea et al., 2010). The results of the tool do not reflect either the economic conditions of both towns, the social acceptance of an incineration or anMBT plant, or the infrastructure and/or existence of the recycling market for secondary materials.

Uncertainties of results. The data for the life cycle inventory of the LCA-IWM assessment tool are common data sets for emissions of pollutants and resources and are used for the ecological assessment. The origin of these data sets is from countries with an advanced developed waste management system and are based on scientifically analysed data, for example air emissions from a landfill, which is determined under Central European conditions such as climate.

In this context there are different studies. For example, Cherubini et al. (2009) also used an LCA software tool (SPIonexcel) to analyse the emissions from different waste management strategies/scenarios. They determined that emissions on global and local scales differ, especially for their scenario 2 'municipal solid waste sorting plant'. The positive results on a global level (a credit) became a negative result at the local level (a burden). The scenarios developed within the present study are similar to those of Cherubini et al. (2009), and these scenarios were assessed on the global level 'world inhabitant equivalents'. Under the condition that each software tool would produce similar results, it can be assumed there is a risk of the environmental assessment of the 'aeMBT' or 'anMBT' scenarios on the local level being incorrect. Turconi et al. (2011) also proved that site-specific data are essential for consistent data. Additionally, the results for global warming of the scenario 'landfill' and scenario 5 'landfill with $20 \%$ recycling' could have less environmental burden as it can be assumed that there is a lower production of biogas under Siberian versus European climatic conditions. Niskanen et al. (2009) also confirmed that a detailed dataset about special parameters such as gas composition or gas production from the landfill, which can be entered in the LCA model need to be obtained in order to get reliable results. Thereafter, improvement of the landfill can be planned. The time period chosen for the landfilling process also plays a significant role
(Finnveden, 1999). Fallaha et al. 2009 supported that LCA results can set the annual production of climate change contributors (such as methane) and therefore, users of LCA such as representatives of urban administration can identify the contributors for each scenario and can reach a decision.

Nevertheless, it is apparent that the recovery of energy through gas utilization within a waste incineration process has a positive environmental impact and lowers the environmental burden for these scenarios (compare also Christensen et al. 2007; De Feo and Malvano 2009; Hong et al., 2010).

In conclusion, as data on the local level in Siberia for the life cycle inventory does not exist, uncertainties within the scenarios of landfilling can be assumed. Research of local data sets from Siberia for the life cycle inventory is necessary.

Recommendations for optimal use of an LCA tool as part of development of a sustainable waste management plan. An LCA tool can support the environmental assessment of various scenarios for a potential waste treatment. However, the use of an LCA tool requires reliable basic data such as waste amount and composition, which have to be determined within a waste analysis. The outcome of the publication demonstrates irrefutably that a lack of reliable data or arbitrary use of the tool can produce incorrect results. Furthermore, the socio-cultural development of each town is unique in all respects and must be factored in when developing a sustainable waste management plan which is not part of an LCA tool.

Finally, an LCA tool is an effective tool for comparing different scenarios. Nevertheless, LCA tools should be used carefully, and the results should be questioned critically. Emery et al. (2007) also explained that LCA should not be used as a substitute for a decision; it can only support a decision regarding waste management plans. It can be said that an LCA assessment tool can support but not replace a decision about the development of a sustainable waste management plan.

\section{Conclusions}

An environmental assessment of different waste treatment scenarios was implemented via the LCA-IWM assessment tool. It was the first time an LCA tool was used in Khanty-Mansiysk and Surgut.

The environmental assessment for this study region showed the following key results.

- Even under Siberian conditions assuming low gas generation rates, the status quo scenario (scenario 1: 'landfill') demonstrates the greatest environmental burden. All other treatment options show less environmental burden and in some cases, environmental credit.

- Despite the logistical challenges, recycling is also a desirable option in Siberia from an environmental perspective.

The following applies for the use of the LCA-IWM assessment tool as a decision-making process. 
- Empirical waste analyses are required in order to get sitespecific data required for the correct use of the tool.

- Spatial circumstances such as distance play an important role for an environmental assessment.

- Socio-cultural progress is different in each town and has to be taken into serious consideration when developing a sustainable waste management plan. That is also implied for the further decision-making process that the environmental assessment has to be extended to economic and social criteria before reaching a final decision on a sustainable waste management plan.

- There are default data within the LCA-IWM assessment tool that may not be suited to the specific Siberian situation. These include the default data of typical emissions which contribute to global warming (methane on a landfill). Therefore, there may be uncertainty in the results with respect to the quantity of emissions within the impact category 'global warming' as the assessment was done on a global versus local level. Further research on default data about local conditions in Siberia is necessary.

\section{Acknowledgements}

Julia Kaazke would like to express special thanks to the Konrad Adenauer Foundation and the International Bureau of the Federal Ministry of Education and Research in Germany for funding her travels to Khanty-Mansiysk. Without the financial support of both institutions, implementation of the research would not have been possible.

\section{Funding}

The study was funded by the Konrad Adenauer Foundation and the International Bureau of the Federal Ministry of Education and Research in Germany.

\section{References}

Administration of Khanty-Mansiysk Autonomous Okrug - Ugra (2011a) Available at: http://www.admhmao.ru/english/obsvedE/frame1.htm (accessed 4 June 2011).

Administration of Khanty-Mansiysk Autonomous Okrug - Ugra. (2011b) Available at: http://www.admhmao.ru/english/obsvedE/frame3.htm (accessed 4 June 2011).

Administration of Khanty-Mansiysk Autonomous Okrug - Ugra. (2011c) Available at: http://www.admhmao.ru/english/obsvedE/frame5.htm (accessed 4 June 2011).

Bovea MD, et al. (2010) Environmental assessment of alternative municipal solid waste management strategies. A Spanish case study. Waste Management 30: 2383-2395.

Cariboni J, et al. (2007) The role of sensitivity analysis in ecological modelling. Ecological Modelling 203: 167-182.

Cherubini F, et al. (2009) Life cycle assessment (LCA) of waste management strategies: Landfilling, sorting plant and incineration Energy. 34: 2116-2123.

Christensen TH, et al. (2007) Experience with the use of LCA-modelling (EASEWASTE). Waste Management and Research 25: 257-262.

Constitution of the Russian Federation (1993) 12 December 1993. Last update 30 December 2008 N 6-FKS/ N 7-FKS.

De Feo G and Malvano C (2009) The use of LCA in selecting the best MSW management system. Waste Management 29: 1901-1915.
Den Boer J, et al. (2007) LCA-IWM: A decision support tool for sustainability assessment of waste management systems. Waste Management 27: 1032-1045.

DIN (Deutsches Institut für Normung e.V.) (2006) ISO 14 040:2006 seriesEnvironmental Management-LCA-Principles and Framework, 2nd Edition., pp.28.

EC (European Commission) (2001) Guidance on EIA - EIS Review. pp. 29, Luxembourg: EC. Available at: http://ec.europa.eu/environment/eia/eiaguidelines/g-review-full-text.pdf (accessed 4 June 2011).

Emery A, et al. (2006) Environmental and economic modelling: A case study of municipal solid waste management scenarios in Wales. Resources, Conservation and Recycling 49: 244-263.

Eriksson O, et al. (2002) ORWARE - a simulation tool for waste management. Resources, Conservation and Recycling 36: 287-307.

Fallaha S, et al. (2009) Broadening GHG accounting with LCA: application to a waste management business unit. Waste Management and Research 27: 885-893.

Federal Law on Industrial and Municipal Waste (1998) № 89, 24 June 1998. Last update 30 December 2008. N 309-FL.

Fillipova I (2011) Ugara, Russia: Ugra State University, Department of Ecology. Finnveden G (1999) Methodological aspects of life cycle assessment of integrated solid waste management systems. Resources, Conservation and Recycling 26: 173-187.

Gentil EC, et al. (2010) Models for waste life cycle assessment: Review of technical assumptions. Waste Management 30: 2636-2648.

Government of Khanty-Mansiysk Autonomous Okrug - Ugra (2004). Atlas. Khanty-Mansiysk Autonomous Okrug - Ugra. Nature and Ecology. Unit II, p. 152.

Hauschild. M. \& Barlaz, M.A. (2010): LCA in waste management: Introduction to principle and method. In Christensen, T. H. (Eds.), Solid Waste Technology \& Management, Chapter 3.1. Chichester, UK: John Wiley \& Sons, Ltd.

Helton JC, et al. (2006) Survey of sampling-based methods for uncertainty and sensitivity analysis. Reliability Engineering and System Safety 91: $1175-1209$.

Hong J, et al. (2010) Life cycle assessment of four municipal solid waste management scenarios in China. Waste Management 30: 2362-2369.

Kaazke J (2010) Environmentally orientated research on solid household waste management in Khanty-Mansiysk Autonomous Okrug - Ugra, Russia. Technische Universität Dissertation. Available at: http://nbnresolving.de/urn:nbn:de:kobv:83-opus-27399 (accessed 25 June 2011).

Kornienko Y (2011) Written interview, Deputy Director of Department for Architecture, Housing and Communal Service (21 March 2011).

Lipworth S. (2008) Royal Society of Chemistry. Environment, Health and Safety Committee Environmental Risk Assessment. London, UK: Royal Society of Chemistry. Available at: http://www.rsc.org/images/ Environmental_Risk_Assessment_tcm18-122341.pdf (accessed 4 June 2011).

Luoranen M, et al. (2009) Comparison of energy und material recovery of household waste management from the environmental point of view - Case Kaunas; Lithuania. Applied Thermal Engineering 29: 938-944

Niskanen A, et al. (2009) Environmental assessment of Ämmässuo Landfill (Finland) by means of LCA-modelling (EASEWASTE). Waste Management and Research 27: 542-550.

OECD (Organization for Economic Co-operation and Development) (2008) Working Group on Waste Prevention and Recycling. A Study on Methodologies Relevant to the OECD Approach on Sustainable Materials Management, pp. 40. Paris, France: OECD.

TU Darmstadt (2005). The Use of Life Cycle Assessment Tool for the Development of Integrated Waste Management Strategies for Cities and Regions with Rapidly Growing Economies (LCA-IWM), European Commission's 5th Framework Programme under the Work Programme 'Energy, Environment and Sustainable Development'. Darmstadt, Germany: TU Darmstadt.

Tukker A (2000) Life cycle assessment as a tool in environmental impact assessment. Environmental Impact Assessment Review 20: 435-456. 
Turconi R, et al. (2011) Life cycle assessment of waste incineration in Denmark and Italy using two LCA models. Waste Management and Research 29: 78-90.

United Nations Environment Programme, Division of Technology, Industry and Economics (2004) Waste Management Planning. An Environmental Sound Approach for Sustainable Urban Waste Management. An Introductory Guide for Decision-makers. Nairobi, Kenya: UNEP, pp. 18
Unger N, et al. (2008) General Requirements for LCA Software Tools. Vienna, Austria: (BOKU) University of Natural Resources and Applied Life Sciences, Institute of Waste Management, p. 6.

Zhao Y, et al. (2009) Life-cycle assessment of the municipal solid waste management system in Hangzhou, China (EASEWASTE). Waste Management and Research 27: 399-406. 